Claremont Colleges

Scholarship@ Claremont

All HMC Faculty Publications and Research

HMC Faculty Scholarship

9-1-2003

\title{
Use of Pulsed-UV Processes to Destroy NDMA
}

Sun Liang

Joon H. Min

Marshall K. Davis

James F. Green

Donald S. Remer

Harvey Mudd College

\section{Recommended Citation}

Liang, Sun, Joon H. Min, Marshall K. Davis, James F. Green, and Donald S. Remer, "Use of Pulsed-UV Processes to Destroy NDMA." Journal AWWA 95.9 (September 2003): 121-131.

This Article is brought to you for free and open access by the HMC Faculty Scholarship at Scholarship @ Claremont. It has been accepted for inclusion in All HMC Faculty Publications and Research by an authorized administrator of Scholarship @ Claremont. For more information, please contact scholarship@cuc.claremont.edu. 


\section{emerging issues}

BY SUN LIANG,

JOON H. MIN,

MARSHALL K. DAVIS,

JAMES F. GREEN, AND

DONALD S. REMER
Bench-scale experiments were conducted to determine the effectiveness of using pulsedultraviolet (UV) irradiation and pulsed-UV/hydrogen peroxide $\left(\mathrm{H}_{2} \mathrm{O}_{2}\right)$ processes to destroy $\mathrm{N}$ nitrosodimethylamine (NDMA). The effects of various UV and $\mathrm{H}_{2} \mathrm{O}_{2}$ dosages and source waters, as well as nitrate $\left(\mathrm{NO}_{3}{ }^{-}\right)$and initial NDMA concentrations, were investigated as control parameters for both completely mixed batch reactor and continuously stirred tank reactor tests. The presence of compounds that interfere with UV light (e.g., $\mathrm{NO}_{3}^{-}$) and the formation of total trihalomethanes after pulsed-UV treatment were also studied. Pulsed-UV technology was highly effective for destroying NDMA. The pseudo-first-order rate constants were calculated to be in the range of 1.4 to $12.2 \mathrm{~min}^{-1}$. This technology offers other benefits (e.g., disinfection) and can be applied directly to drinking water treatment. However, potential concerns in pulsed-UV photolysis of NDMA include (1) the formation of undesirable chemicals as reaction intermediates and (2) possible reformation/regeneration of NDMA after chlorination of pulsed-UV-treated effluent. Pulsed-UV with a small amount of $\mathrm{H}_{2} \mathrm{O}_{2}$ could be used to control the reaction by-products and to inhibit the reformation of NDMA by using hydroxyl radicals generated during an advanced oxidation process. In contrast, pulsed-UV with a larger amount of $\mathrm{H}_{2} \mathrm{O}_{2}$ could inhibit NDMA decay by direct photolysis.
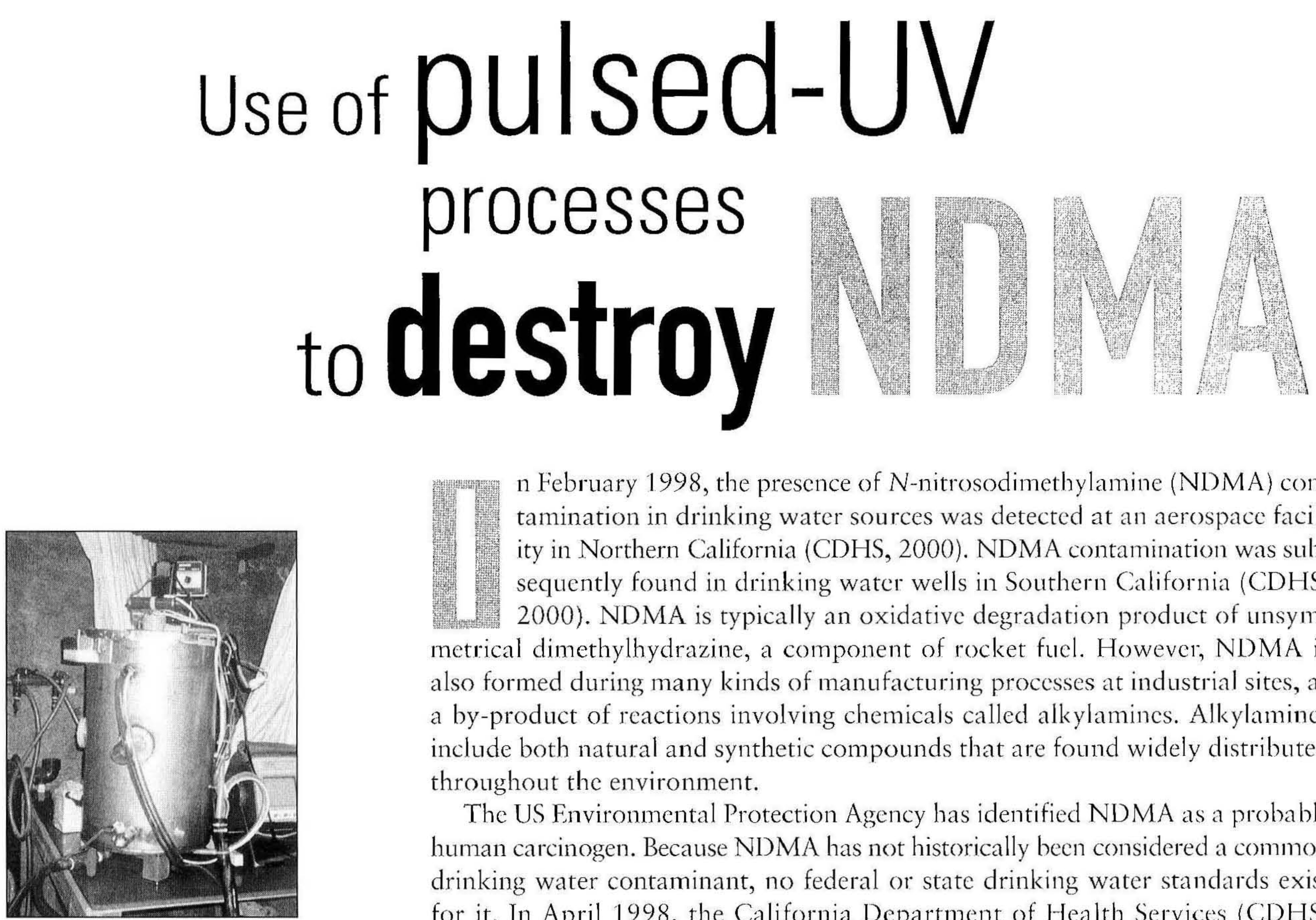

n February 1998, the presence of N-nitrosodimethylamine (NDMA) contamination in drinking water sources was detected at an aerospace facility in Northern California (CDHS, 2000). NDMA contamination was subsequently found in drinking water wells in Southern California (CDHS, 2000). NDMA is typically an oxidative degradation product of unsymmetrical dimethylhydrazine, a component of rocket fuel. However, NDMA is also formed during many kinds of manufacturing processes at industrial sites, as a by-product of reactions involving chemicals called alkylamines. Alkylamines include both natural and synthetic compounds that are found widely distributed throughout the environment.

The US Environmental Protection Agency has identified NDMA as a probable human carcinogen. Because NDMA has not historically been considered a common drinking water contaminant, no federal or state drinking water standards exist for it. In April 1998, the California Department of Health Services (CDHS) announced an action level of $2 \mathrm{ng} / \mathrm{L}$ for NDMA (CDHS, 2000). The level of NDMA found in a Northern California drinking water well in eastern Sacramento County was approximately $150 \mathrm{ng} / \mathrm{L}$. (CDHS, 2000). In Southern California, NDMA in the range of 70 to $3,000 \mathrm{ng} / \mathrm{L}$ (CDHS, 2000) was found in three drink- 


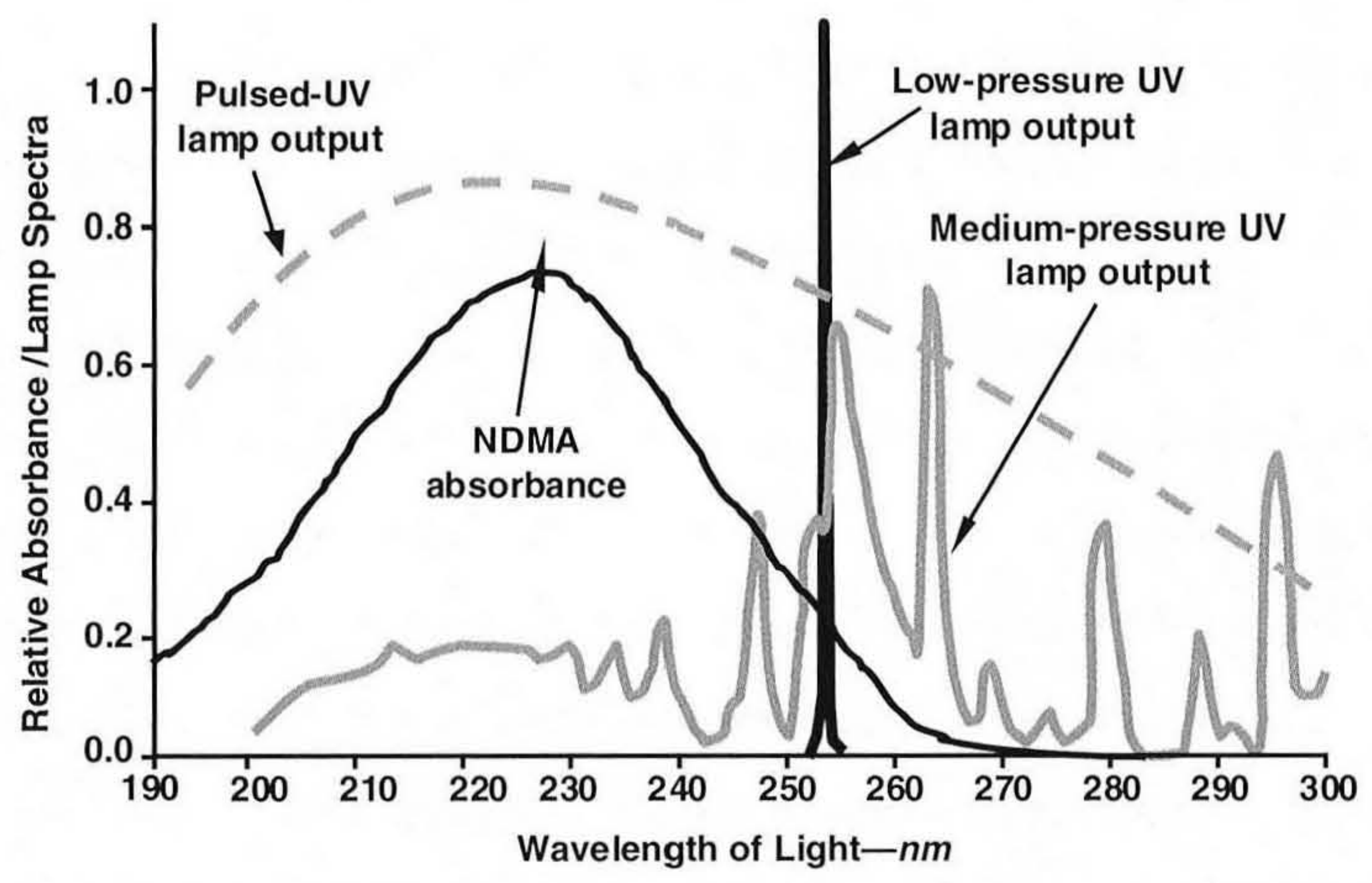

NDMA-N-nitrosodimethylamine, UV—ultraviolet

ing water wells in the San Gabriel Basin. It has recently been suggested that NDMA may be present in (1) sewage and reclaimed water after chlorination (Brennan \& Robbins, $2000)$ and (2) surface water processed by conventional drinking water treatment methods (Choi et al, 2001; Davis et al, 2000). Although the exact mechanisms of NDMA formation are unknown, they appear to be associated with the chlorination process. In December 1999, the CDHS established a "temporary" action level of $20 \mathrm{ng} / \mathrm{L}$ for NDMA so that more utilities could participate in the initial screening effort. In March 2002, the CDHS revised its temporary action level to $10 \mathrm{ng} / \mathrm{L}$ (CDHS, 2003).
The current widespread detection of NDMA and its changing regulatory status point to the need for a technology that can remediate drinking water sources contaminated by this compound. It is well known that NDMA can be reduced by ultraviolet (UV) technologies (Sharpless et al, 2001; Bolton et al, 2001; Calgon Carbon, 1996). Pulsed-UV has the potential to provide much more complete oxidation of NDMA because of its ability to deliver much higher UV light intensities than other continuous-wave UV technologies. In addition, pulsed-UV/hydrogen peroxide $\left(\mathrm{H}_{2} \mathrm{O}_{2}\right)$, which uses the generation of hydroxyl radicals, is expected to react with NDMA and further break down intermediate NDMA degradation by-products to avoid the reformation of NDMA after chlorination. Therefore, there is a growing interest in pulsed-UV and pulsed-UV/ $\mathrm{H}_{2} \mathrm{O}_{2}$ treatment processes for removing NDMA from drinking water.

\section{BACKGROUND}

Physical/chemical properties of NDMA. NDMA is the simplest dialkylnitrosamine, with a molecular formula of $\mathrm{C}_{2} \mathrm{H}_{6} \mathrm{~N}_{2} \mathrm{O}$. It is a volatile, combustible, yellow, oily liquid (MOE, 1991). NDMA has a high water solubility (Table 1) and a low octanol-water-partitioning coefficient $\left(\log K_{o w}=-0.51\right)$ and can readily leach into groundwater. In addition, NDMA is not likely to bioaccumulate, adsorb to particulate, or volatilize (because of a low Henry's law constant, $2.63 \times 10^{-7}$ atm$\mathrm{m}^{3} / \mathrm{mol}$ ), which enhances its potential to move through soil and sediment into groundwater.

Pulsed-UV irradiation. Pulsed-UV irradiation uses high-intensity UV flash lamps. Flash lamps operate in the pulsed mode with peak intensities much greater than those that occur with continuous sources of the same average power. The pulse duration is typically in the microsecond time scale, whereas the interval between pulses is on the order of milliseconds. The electrical discharge quickly heats the fill gas to a high enough temperature $(\sim 15,000 \mathrm{~K})$ to create a plasma that emits blackbody light characteristic of its temperature. Unique features of pulsed lamps include the ability to come to full power immediately (without a warmup period) and the ability 
to shift the spectrum of a single lamp by simply changing the peak pulse power. Unlike low- or medium-pressure mercury-based lamps, commonly used fill gases for pulsed-UV lamps include xenon, argon, and other inert gases or mixtures. Thus, lamp breakage does not pose any significant challenges compared with those from the mercury-based lamps. Xenon plasmas generally have the greatest efficiency for photon production.

Pulsed-UV treatment systems are polychromatic in nature, providing continuous spectra between the wavelengths of 185 and $1,000 \mathrm{~nm}$. With high plasma temperature occurring during pulsing, the low-wavelength emission reaches maximum energy level. A typical xenon flash lamp is maximized at $230 \mathrm{~nm}$ and has significant output at wavelengths below 200 $\mathrm{nm}$ (Figure 1). However, excessively high pulse energies increase thermal stresses and may shorten the life of a lamp. Pulsed-UV flash lamp intensitics of several hundred to $1,000 \mathrm{~W} / \mathrm{in}$. (discharge length) contrast with a few hundred watts per inch for lowand medium-pressure mercury lamps. The greater power density may allow the use of a shorter contact time or a smaller contactor.

Photolysis and oxidation of NDMA. NDMA absorbs UV light in a strong band centered at $228 \mathrm{~nm}$ (Figure 1) and a weak band centered at $332 \mathrm{~nm}$, resulting in breakdown of the nitrogen-nitrogen bond in the molecule-the primary mechanism of NDMA removal (Bircher et al, 1999). Because the absorption band is strong, direct photolysis of NDMA by UV technologies alone is a promising treatment process. Pulsed xenon lamps are even more capable of direct photolysis of NDMA than low-pressure mercury lamps because of the greater polychromatic wavelength produced between 200 and $300 \mathrm{~nm}$ (Figure 1).

FIGURE 3 Correlation between hydraulic retention time and UV dose for the pulsed-UV system used

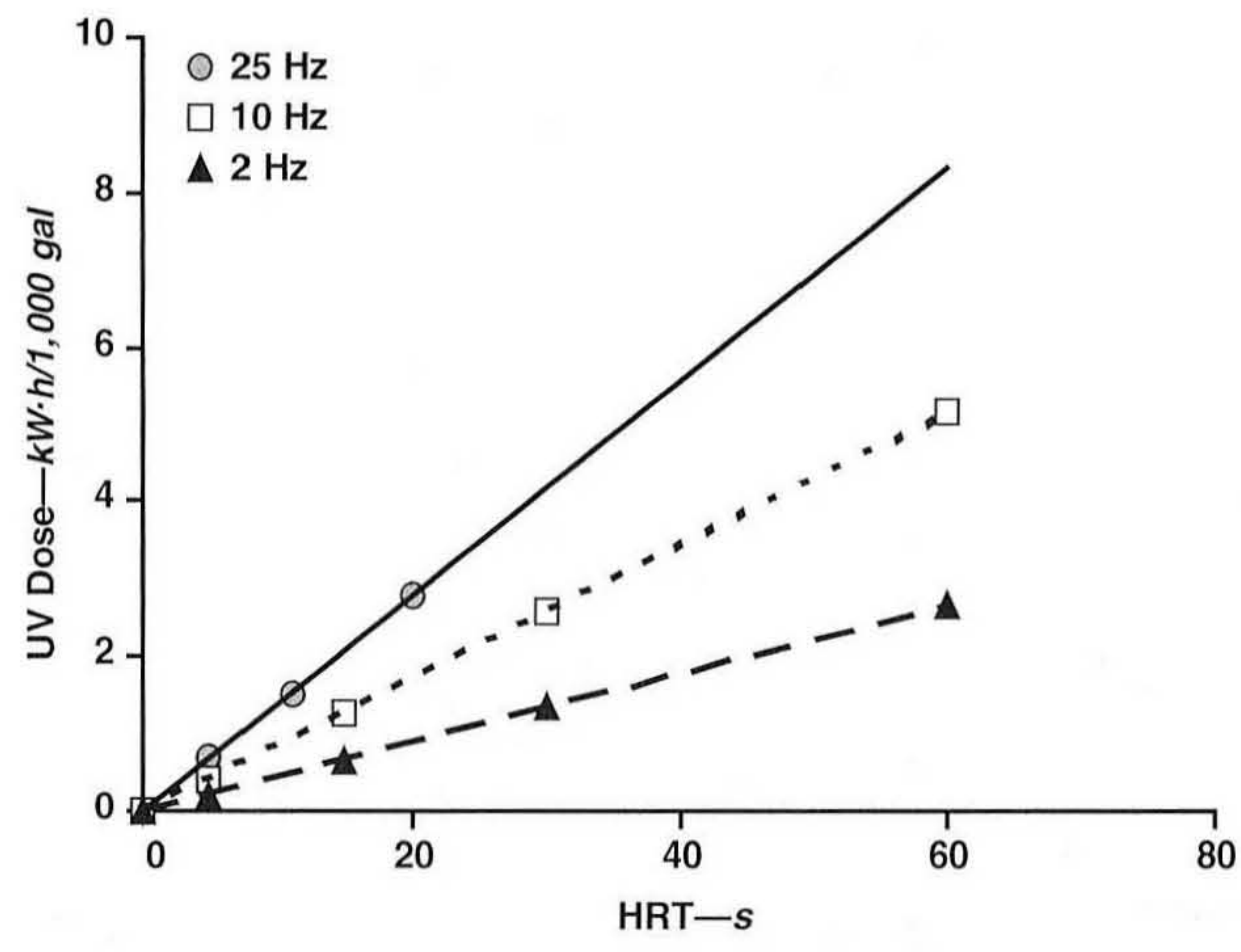

HRT-hydraulic retention time, UV—ultraviolet

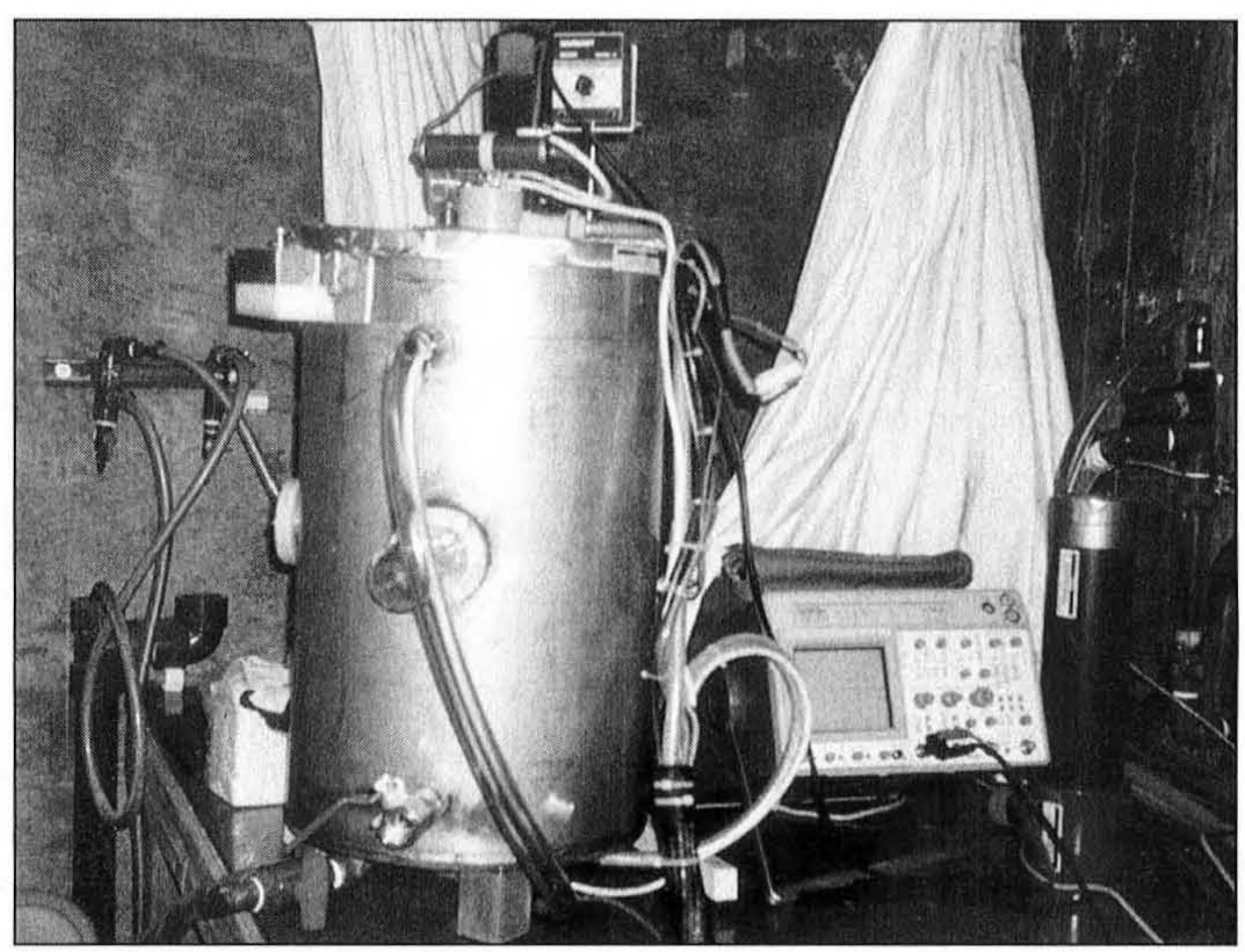

A pulsed-ultraviolet (UV) system can effectively treat water contaminated by $N$-nitrosodimethylamine with the use of a non-mercury-based lamp. Applied UV dosage for a pulsed-UV system can be adjusted easily by changing the lamp's pulse frequency.

When $\mathrm{H}_{2} \mathrm{O}_{2}$ is present during the UV process, hydroxyl radicals $(\cdot \mathrm{OH})$ can be produced by the photolysis of $\mathrm{H}_{2} \mathrm{O}_{2}$, as shown in $\mathrm{Eq} 1$.

$$
\mathrm{H}_{2} \mathrm{O}_{2} \stackrel{h v}{\rightarrow} 2 \cdot \mathrm{OH}
$$

The hydroxyl radicals attack organic compounds nonselectively, with rate constants ranging from $10^{7}$ to $10^{9} \mathrm{~L}$ $\times \mathrm{mol}^{-1} \times \mathrm{s}^{-1}$. The rate constant of NDMA oxidation by hydroxyl radicals is $3.3 \times 10^{8} \mathrm{~L} \times \mathrm{mol}^{-1} \times \mathrm{s}^{-1}$ (Buxton et al, 1988), and this may serve as a secondary NDMA removal mechanism.

\section{LITERATURE REVIEW}

Treatment technologies. Because of NDMA's highly water-soluble, polar nature, it cannot be effectively removed from water using air-stripping, reverse osmosis membranes, or granular activated carbon (Jobb et al, 1994; Jobb et al, 1992). Jobb et al (1994, 1992) showed that low-pressure mercury UV lamp irradiation could reduce NDMA from 89 to $5 \mathrm{ng} / \mathrm{L}$ at a UV dosage of approximately $2.6 \mathrm{~kW} \cdot \mathrm{h} / \mathrm{m}^{3}$ (or $10 \mathrm{~kW} \cdot \mathrm{h} / 1,000 \mathrm{gal}$ ) in the laboratory-scale test. Furthermore, pilot-scale studies (Jobb et al, 1994; Jobb et al, 1992) found that a UV dose of $1.26 \mathrm{~kW} \cdot \mathrm{h} / \mathrm{m}^{3}$ (or $4.85 \mathrm{~kW} \cdot \mathrm{h} / 1,000$ gal) was effective in reducing NDMA to $<5 \mathrm{ng} / \mathrm{L}$. Bircher et al (1999) reported that NDMA was reduced from 53 to 2 $\mathrm{ng} / \mathrm{L}$ in groundwater with a UV dose of $0.39 \mathrm{~kW} \cdot \mathrm{h} / \mathrm{m}^{3}$ $(1.5 \mathrm{~kW} \cdot \mathrm{h} / 1,000 \mathrm{gal})$ produced through a medium-pressure lamp.

Potential destruction pathway for NDMA. When NDMA strongly absorbs UV light in a band centered around $228 \mathrm{~nm}$, an unstable dimethylamino radical and a nitric oxide (NO) radical are initially formed. Bircher et al (1999) proposed that the dimethylamino and NO radi- 


\begin{tabular}{l|l}
\multicolumn{1}{c|}{ Chemical Property } & \multicolumn{1}{c}{ Measurement } \\
\hline Molecular weight & $74.08 \mathrm{~g} / \mathrm{mol}$ \\
Boiling point at $760 \mathrm{mmHg}$ & $151-154{ }^{\circ} \mathrm{C}$ \\
Melting point & $-50^{\circ} \mathrm{C}$ (estimated) \\
Vapor pressure @ 20ㅇ & $2.7 \mathrm{mmHg}$ \\
Vapor density at $25^{\circ} \mathrm{C}$ & $2.56 \mathrm{~g} / \mathrm{L}$ \\
Density at $20^{\circ} \mathrm{C}$ & 1.0048 \\
Solubility & Miscible, $3,978 \mathrm{mg} / \mathrm{L}$ \\
Henry's law at $25^{\circ} \mathrm{C}$ & $2.63 \times 10^{-7} \mathrm{~atm}-\mathrm{m}^{3} / \mathrm{mol}$ (estimated) \\
Log $K_{o c}$ & 1.41 \\
Log $K_{o w}$ & -0.57 \\
&
\end{tabular}

TABLE 2 Raw water quality characteristics

\begin{tabular}{|c|c|c|c|}
\hline Parameters & $\begin{array}{l}\text { Deionized } \\
\text { Water* }\end{array}$ & $\begin{array}{l}\text { Southern } \\
\text { California } \\
\text { Groundwater }\end{array}$ & $\begin{array}{c}\text { Colorado } \\
\text { River } \\
\text { Water }\end{array}$ \\
\hline Total organic carbon- $m g / L$ & 0.11 & 0.17 & 3.04 \\
\hline Electrical conductivity $-\mu m h o s$ & 1.08 & 389 & 919 \\
\hline Nitrate- $m g / L$ & NDt & 1.98 & 1.1 \\
\hline Alkalinity-mg/L & NA $\neq$ & 166 & 131 \\
\hline Turbidity—ntu & NA & 0.07 & 0.88 \\
\hline $\mathrm{pH}-$ unit & 5.4 & 7.76 & 8.29 \\
\hline Ultraviolet absorbance at $254 \mathrm{~nm}-\mathrm{abs} / \mathrm{cm}$ & ND & ND & 0.1 \\
\hline
\end{tabular}

*Super-Q,@ Millipore Corp., Bedford, Mass.

tND-not detected

¥NA-not applicable

\section{FIGURE 4 Effects of pulsed-UV dosages on NDMA reduction in deionized water}

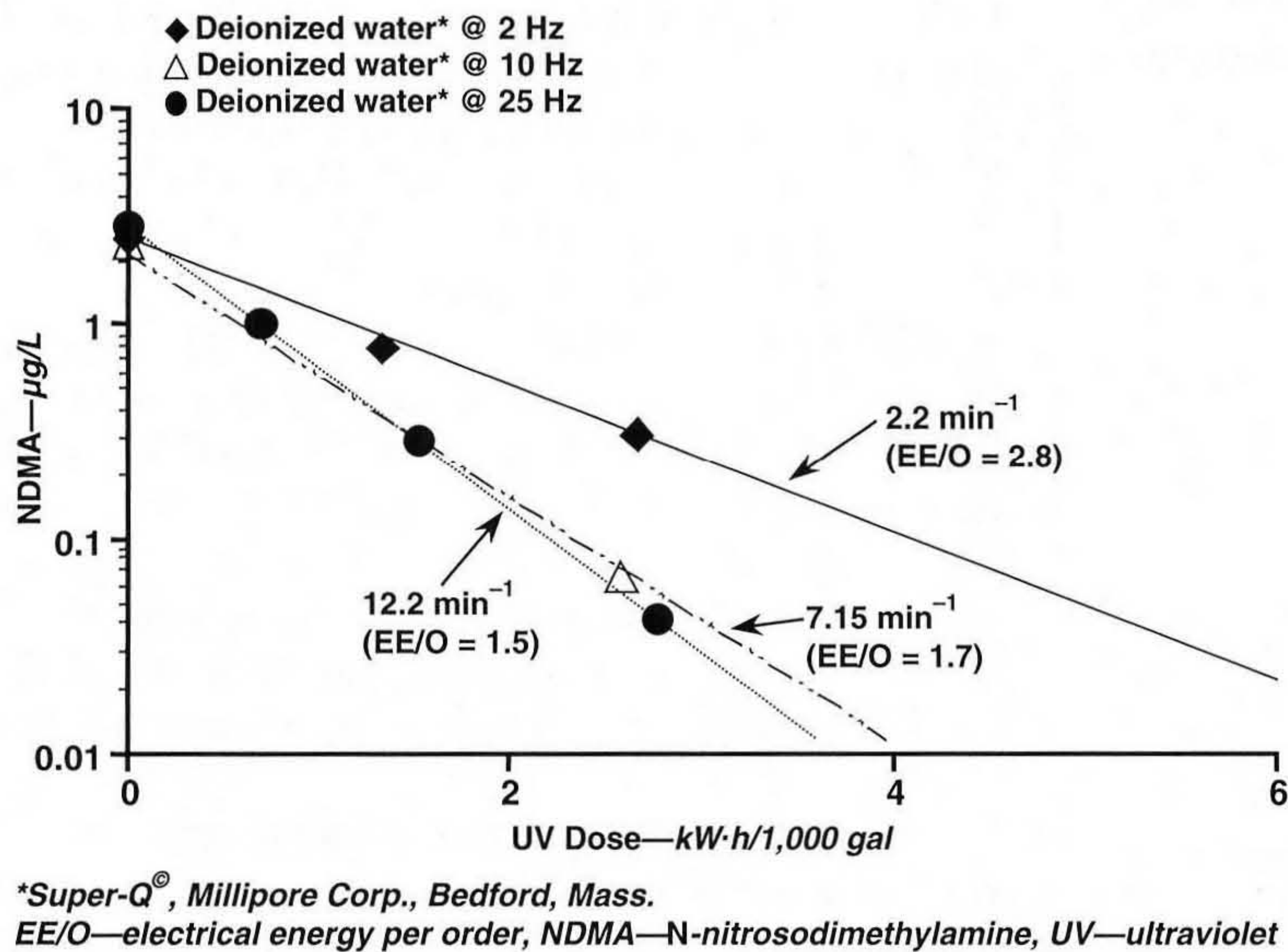

cals could react with a hydroxyl radical and oxygen to become bicarbonate and nitrate $\left(\mathrm{NO}_{3}{ }^{-}\right)$, respectively. The dimethylamino radical has the potential to combine readily with a hydroxyl radical abstracted from a water molecule to form dimethylamine (Challis et al, 1978). Dimethylamine may combine with nitrite to reform NDMA under certain conditions. This might explain the reformation/regeneration of NDMA following chlorination of UV-irradiated water.

\section{OBJECTIVES}

The main objective of this study was to evaluate the effectiveness of pulsed-UV and pulsed-UV/ $\mathrm{H}_{2} \mathrm{O}_{2}$ processes for NDMA removal. The following goals were pursued during the course of the study:

- investigate the effects of pulsedUV dosage on NDMA destruction,

- determine the effects of pulsedUV and $\mathrm{H}_{2} \mathrm{O}_{2}$ dosages in pulsed$\mathrm{UV} / \mathrm{H}_{2} \mathrm{O}_{2}$ processes for NDMA removal,

- evaluate the effects on NDMA destruction exerted by other pulsedUV-absorbing compounds that compete for pulsed-UV light,

- using flowthrough tests, evaluate the effects of pulsed-UV and pulsed-UV/ $\mathrm{H}_{2} \mathrm{O}_{2}$ dosages on various levels of NDMA, and

- investigate the possible reformation/regeneration of NDMA in water treated with pulsed-UV.

\section{EXPERIMENTAL DESIGN}

Batch reactor description. The pulsed-UV system ${ }^{1}$ consisted of a 316 -grade stainless-steel batch reactor that included a mixer, a $5-\mathrm{kW}$ power source, and a $15-\mathrm{cm}$ xenonfilled, tungsten-electrode lamp ${ }^{2}$ inside a quartz jacket-a conduit for deionized (DI) cooling water. For benchtop experiments, this lamp arrangement was housed inside a treatment chamber that could be operated as either a completely mixed batch reactor (CMBR) or a continuously stirred tank reactor (CSTR) system (Figure 2). With power applied to the lamp, 
a standby "simmer mode" of steadystate partial ionization of the xenon gas was maintained with a low-current arc between the electrodes (Smith, 1986). Pulses were generated by an electrical discharge that quickly heated the xenon gas and created a plasma of ionized gas, which reached a temperature high enough (near $15,000 \mathrm{~K}$ ) to emit blackbody light radiation from 185 to $400 \mathrm{~nm}$ and above. The electrical hardware allowed the bulb to operate up to $30 \mathrm{flashes} / \mathrm{s}$.

In the CMBR experiments, the pulsed-UV reaction volume was 10 or $12 \mathrm{gal}\left(0.038\right.$ or $\left.0.045 \mathrm{~m}^{3}\right)$, and samples were taken from the reactor after various exposure times. In the CSTR experiments, the pulsed-UV reaction volume was $13 \mathrm{gal}\left(0.049 \mathrm{~m}^{3}\right)$ with a flow rate of $7.4 \mathrm{gpm}\left(0.028 \mathrm{~m}^{3} / \mathrm{min}\right)$. The samples were collected after approximately four retention times. Both US pharmaceutical-grade $\mathrm{H}_{2} \mathrm{O}_{2}$ (at $3 \%$ by weight) and $\mathrm{NDMA}^{3}$ (at 5,000 $\mu \mathrm{g} / \mathrm{mL}$ ) were prespiked to a desired concentration, when appropriate, into $5 \mathrm{gal}\left(0.019 \mathrm{~m}^{3}\right)$ carboys in the fume hood. The NDMAspiked carboys were covered in black plastic bags to avoid any exposure to sunlight during transfer to the reactor.

Bench-scale tests. The pulsed-UV irradiation and pulsed-UV/ $/ \mathrm{H}_{2} \mathrm{O}_{2}$ tests for NDMA reduction were conducted in two phases. The study tested three types of water: organic-free DI water, ${ }^{4}$ Colorado River water (CRW), and a Southern California groundwater. The first phase of testing was performed in a CMBR to determine (1) the required pulsed-UV dosage and $\mathrm{H}_{2} \mathrm{O}_{2}$-to-NDMA ratios for NDMA oxidation and (2) the optimum retention time for NDMA destruction. The effects of other compounds (e.g., $\mathrm{NO}_{3}^{-}$) on NDMA destruction and the possible reformation of NDMA were also investigated in the CMBR setup. The second-phase tests were conducted in a CSTR to investigate the effects of two influent NDMA concentrations (100 and 3,000 ng/L) on NDMA removal and to validate the optimized conditions for NDMA removal with a pulse frequency of $25 \mathrm{~Hz}$ and a hydraulic retention time (HRT) of $1.75 \mathrm{~min}$.

Sampling. DI water, CRW, and groundwater pumped from the Southern California region were analyzed for turbidity, $\mathrm{pH}$, alkalinity, conductivity, bromide, $\mathrm{NO}_{3}^{-}, \mathrm{UV}$

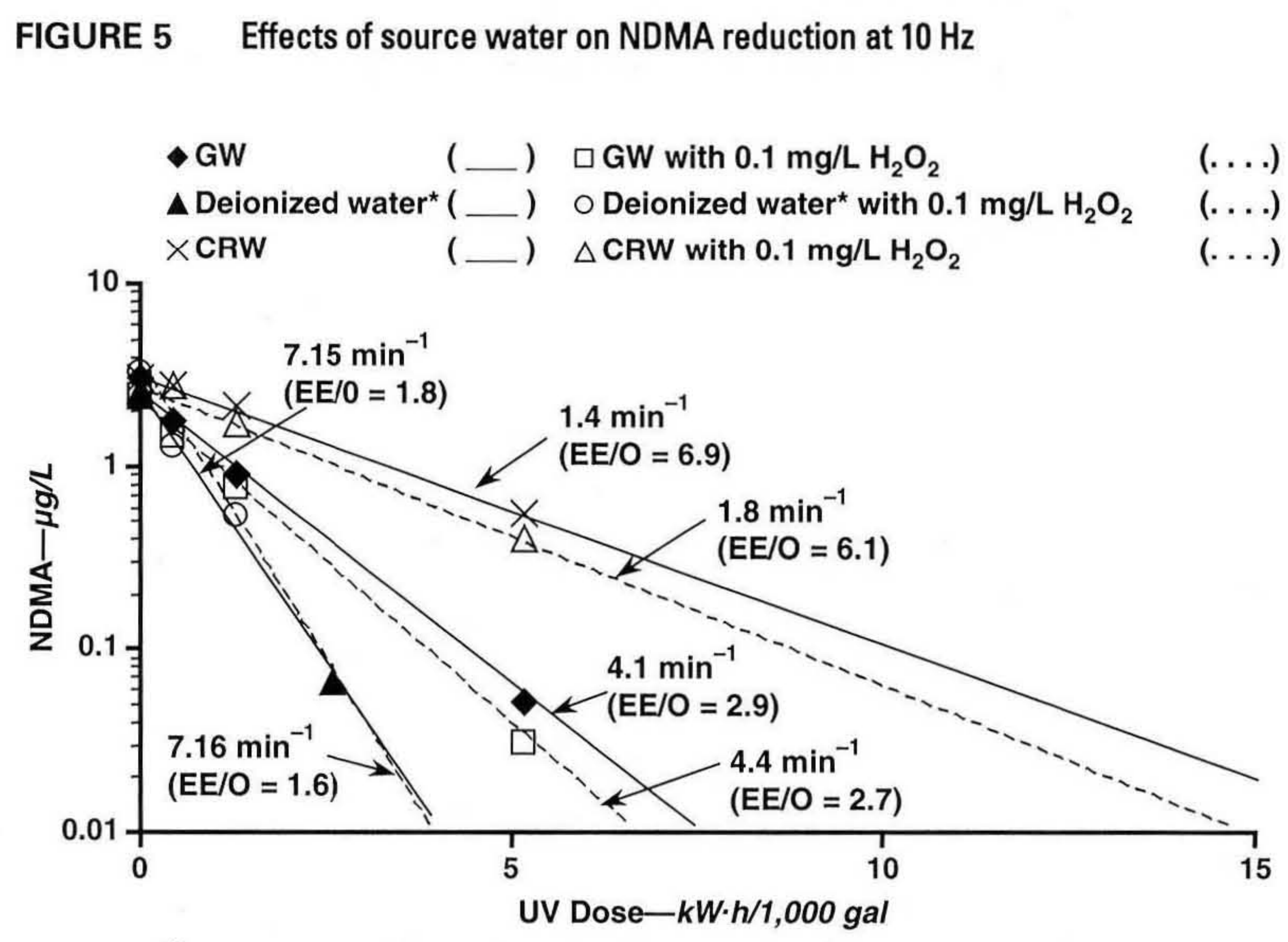

*Super- $Q^{\odot}$, Millipore Corp., Bedford, Mass.

CRW-Colorado River water, EE/O-electrical energy per order, GW-groundwater, $\mathrm{H}_{2} \mathrm{O}_{2}$-hydrogen peroxide, NDMA-N-nitrosodimethylamine, UV-ultraviolet

\section{FIGURE 6 Effects of nitrate on NDMA reduction in deionized water* at $10 \mathrm{~Hz}$}

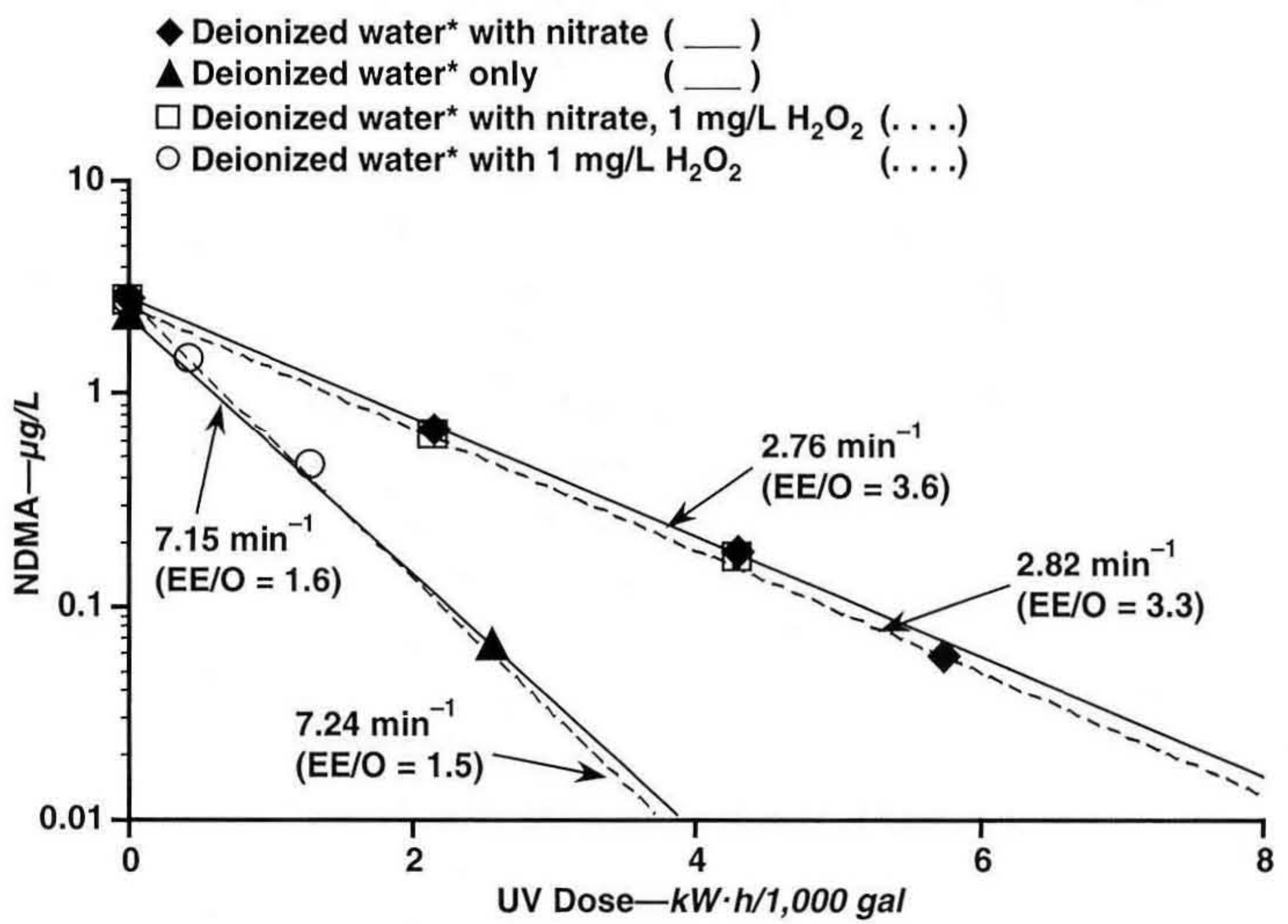

Super- $Q^{\odot}$, Millipore Corp., Bedford, Mass.

EE/O-electrical energy per order, $\mathrm{H}_{2} \mathrm{O}_{2}$-hydrogen peroxide, NDMA-N-nitrosodimethylamine, UV-ultraviolet 


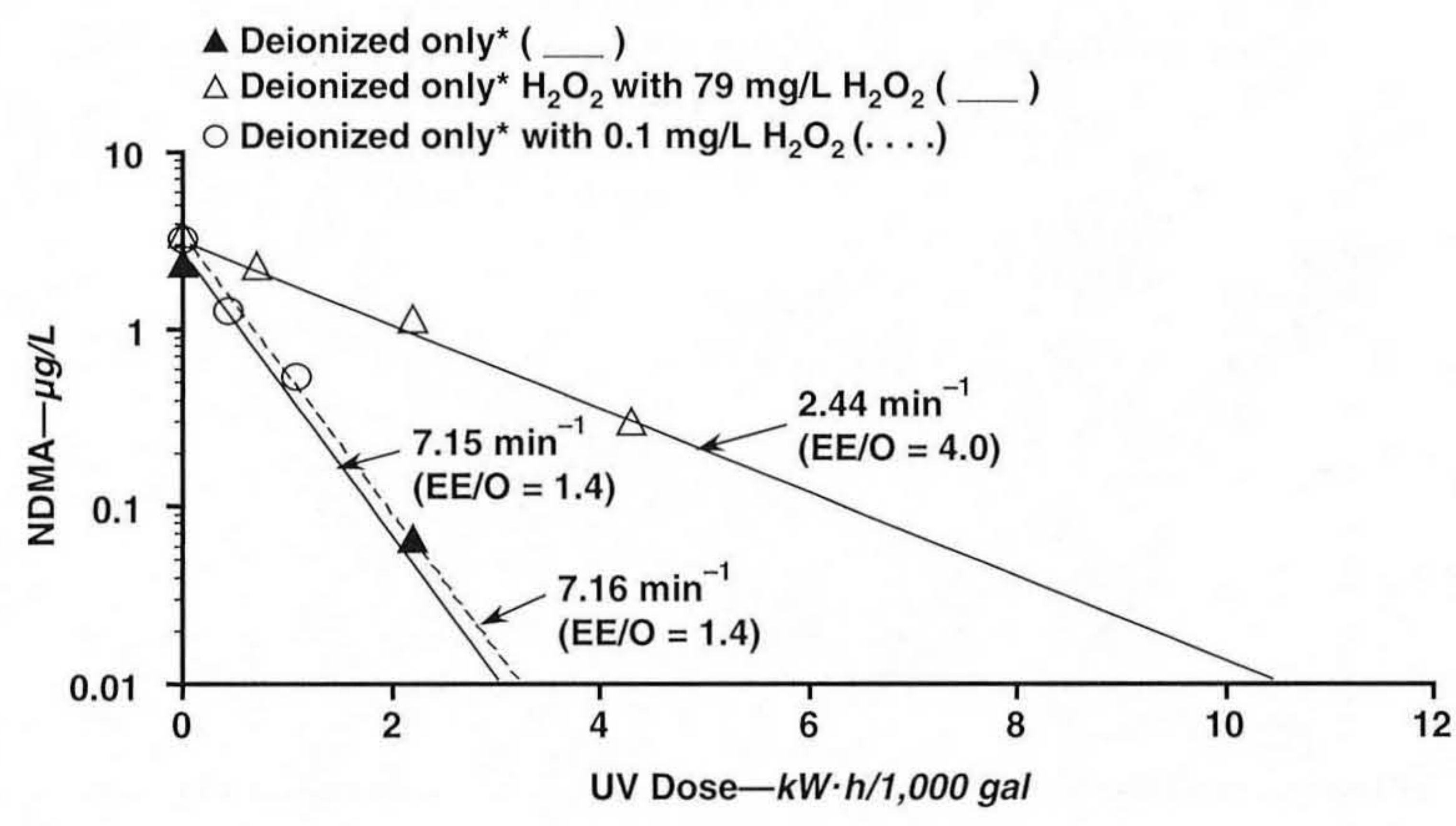

${ }^{\star}$ Super- $Q^{\odot}$, Millipore Corp., Bedford, Mass. EE/O-electrical energy per order, $\mathrm{H}_{2} \mathrm{O}_{2}$ - hydrogen peroxide, NDMA-N-nitrosodimethylamine, UV-ultraviolet

fied THM liquid-liquid extraction as described by Koch et al (1988).

\section{RESULTS AND DISCUSSION}

Raw water quality. The pertinent raw water quality parameters of the water tested in this study are listed in Table 2. In general, DI water contains low TOC concentrations, low conductivity, and nondetectable levels of $\mathrm{NO}_{3}{ }^{-}$and $\mathrm{UV}_{254}$ absorbing organic compounds. CRW typically contains high concentrations of TOC, conductivity, turbidity, and $\mathrm{UV}_{254}$-absorbing organic compounds. The groundwater selected for this study contained high concentrations of total alkalinity, low concentrations of TOC and turbidity, and $\mathrm{NO}_{3}{ }^{-}$at approximately $2 \mathrm{mg} / \mathrm{L}$.

The characteristics of the water can play an important role in UV treatment. For example, high turbidity

analysis was conducted in accordance with the procedures described in Standard Methods (1995), except as noted in the following paragraphs.

Residual $\mathrm{H}_{2} \mathrm{O}_{2}$. The analyses for $\mathrm{H}_{2} \mathrm{O}_{2}$ residual involved the reactions of $\mathrm{H}_{2} \mathrm{O}_{2}$ with $p$-hydroxy-phenylacetic acid and horseradish peroxidase, followed by detection of the fluorescent product by a fluorescence spectrophotometer, ${ }^{5}$ as described by Kok et al (1986).

NDMA. Prior to June 1999, NDMA samples were analyzed by a contract laboratory, ${ }^{6}$ which extracted NDMA samples by continuous liquid-liquid extraction and analyzed the extract by gas chromatography/mass spectrometry (GC/MS), using a selected ion-monitoring mode to determine NDMA. This method has a detection limit of $20 \mathrm{ng} / \mathrm{L}$. NDMA samples taken after June 1999 were analyzed at the Canadian Ministry of the Environment, Etobicoke, Ont. NDMA was analyzed by a solidphase extraction method combined with low-resolution GC/MS, as described by Taguchi et al (1994). This method has a detection limit of $1 \mathrm{ng} / \mathrm{L}$. Before the NDMA samples were submitted for analysis, catalase was spiked into the samples to quench the residual $\mathrm{H}_{2} \mathrm{O}_{2}$ and prevent any further NDMA reaction.

Simulated distribution system (SDS) tests. The water samples were dosed with chlorine at $1.5 \mathrm{mg} / \mathrm{L}$ in the laboratory and incubated at $25^{\circ} \mathrm{C}$ for one day. The chlorine dosage of $1.5 \mathrm{mg} / \mathrm{L}$ was chosen because preliminary chlorine demand tests indicated that this was the dosage needed to maintain a residual of at least 0.2 $\mathrm{mg} / \mathrm{L}$ after $24 \mathrm{~h}$. Analyses were conducted on SDS samples to evaluate the formation of pentane-extractable disinfection by-products (DBPs)--such as total trihalomethanes (TTHMs), haloacetonitriles (HANs), haloketones (HKs), and chloropicrin-that used modi- lowers the transmittance of the source water, thus lowering the penetration of the UV for effective photolysis. Also, water with constituents that strongly absorb UV light (such as $\mathrm{NO}_{3}^{-}$) can compete for UV light with NDMA, thus reducing removal efficiency.

NDMA removal. The following discussion of NDMA removal examines the effects of pulsed-UV dosage, source water, $\mathrm{H}_{2} \mathrm{O}_{2}$, and $\mathrm{NO}_{3}{ }^{-}$, as well as the effects of initial NDMA concentration. Overall, effective reduction of NDMA was observed for most of the test conditions used. A pseudo-first-order kinetic model can fit NDMA removal data as described in $\mathrm{Eq} 2$.

$$
\ln \left(C / C_{0}\right)=-k t
$$

in which $C$ is the NDMA concentration $(\mu \mathrm{g} / \mathrm{L}), C_{0}$ is the initial NDMA concentration $(\mu \mathrm{g} / \mathrm{L}), k$ is the pseudo-firstorder rate constant $\left(\mathrm{min}^{-1}\right)$, and $t$ is time $(\mathrm{min})$.

The calculated pseudo-first-order rates for the conditions used are shown in Figures 3-7 for the conditions used. Rates for each water matrix with $\mathrm{H}_{2} \mathrm{O}_{2}$ are also shown in the figures. For comparison purposes, elcctrical energy per order $(\mathrm{EE} / \mathrm{O})$ values are also included for the pseudo-first-order rates in these figures.

Effects of UV dosage. UV dosage is commonly derived from the product of average UV irradiance and theoretical contact time (or HRT) (Figure 3). For conventional low-pressure UV, UV irradiance is usually measured by collimated beam test equipment (e.g., a joulemeter or radiometer) at bench scale, and residence time distribution is determined by tracer studies. However, reliable determination of UV dosages for CMBR and CSTR systems is much more difficult. This is especially true for polychromatic UV light, such as pulsed UV, because determination 
of the synergistic effect of multiple peaks on the compounds used in dose measurement is more challenging than for the case with single-wavelength, low-pressure UV. As a result, pulsedUV dosage cannot be accurately provided in millijoules per square centimetre. Alternatively, UV dosage can be represented by a measure of total lamp electrical energy applied (power $[\mathrm{kW}] \times$ time $[\mathrm{h}])$ to a fixed volume of water $\left(1,000 \mathrm{gal}\left[3.785 \mathrm{~m}^{3}\right]\right)$ to reflect parameters such as flow rate (or HRT) and lamp energy into a combined number. Therefore, UV dosage in kilowatt hours per 1,000 gal, as described in Eq 3, was used throughout this study.

UV dose $=$ average power input $(\mathrm{kW})$

$$
\begin{aligned}
& \times \frac{\text { residence time }(\mathrm{h})}{\text { reactor volume }(\mathrm{gal})} \\
& \times \frac{1,000 \mathrm{gal}}{1,000 \mathrm{gal}}
\end{aligned}
$$

The energy input to the system was calculated by using the HRT and power requirement from the pulsedUV system (lamp and system) used for this study at $1.6,3.1$, and $5 \mathrm{~kW}$ at 2, 10 , and $25 \mathrm{~Hz}$, respectively. Approximately $1 \mathrm{~kW}$ was a system power requirement, and the remaining energy input was for the lamp.

UV dosage can also be provided in $\mathrm{EE} / \mathrm{O}$ of NDMA destruction. $\mathrm{EE} / \mathrm{O}$ is the UV dosage required for $90 \%$ (1-log) reduction from the initial concentration. $\mathrm{EE} / \mathrm{O}$ values are also provided in this article, when appropriate, to be used in comparing the efficacy of NDMA destruction with that of the more commonly used mercury lamps.

NDMA-spiked DI water was irradiated in the absence of $\mathrm{H}_{2} \mathrm{O}_{2}$ at pulsed-UV frequency inputs of 25 , 10 , and $2 \mathrm{~Hz}$ in a CMBR system. Because DI water contains an insufficient amount of background precursor to generate hydroxyl radicals, the process of NDMA removal is likely to be dominated by direct photolysis of NDMA. It is apparent that the NDMA level decreases with increasing UV dosage (irradiation time) at the same pulse input (frequency), as shown in Figure 4. For exam-

* $\mathrm{NO}_{3}$ - - nitrate

§UV-ultraviolet

+UV-ultraviolet

TABLE 5

\section{TABLE 3 \\ Effects of $\mathrm{NO}_{3}{ }^{-*}$ on NDMAT reduction in deionized water‡ at $10 \mathrm{~Hz}$

\begin{tabular}{|c|c|c|c|c|c|c|}
\hline \multirow[b]{2}{*}{$\begin{array}{c}\text { Irradiation } \\
\text { Time } \\
s\end{array}$} & \multirow[b]{2}{*}{$\begin{array}{c}\text { UV } \\
\text { Dose } \\
k W \cdot h / 1,000 \mathrm{gal}\end{array}$} & \multicolumn{2}{|c|}{ Pulsed-UV§ Alone } & \multicolumn{3}{|c|}{ Pulsed-UV + $1.0 \mathrm{mg} / \mathrm{L} \mathrm{H}_{2} \mathrm{O}_{2}{ }^{* *}$} \\
\hline & & $\begin{array}{c}\text { NDMA } \\
n g / L\end{array}$ & $\begin{array}{l}\mathrm{NO}_{3}^{-} \\
\mathrm{mg} / \mathrm{L}\end{array}$ & $\begin{array}{c}\text { NDMA } \\
\mu g / L\end{array}$ & $\begin{array}{l}\mathrm{NO}_{3}^{-} \\
\mathrm{mg} / \mathrm{L}\end{array}$ & $\begin{array}{c}\mathrm{H}_{2} \mathrm{O}_{2} \\
\text { Residual } \\
\mu \mathrm{g} / \mathrm{L}\end{array}$ \\
\hline 0 & 0 & 2,800 & 38.4 & 2,700 & NAtt & 870 \\
\hline 30 & 2.2 & 690 & NA & 640 & NA & 900 \\
\hline 60 & 4.3 & 180 & NA & 170 & NA & 870 \\
\hline 80 & 5.7 & 58 & 34.1 & NA & NA & NA \\
\hline 120 & 8.6 & NA & NA & 19 & NA & 800 \\
\hline \multicolumn{2}{|c|}{ Percent removal } & $97.9 \%$ & NA & $99.2 \%$ & NA & NA \\
\hline
\end{tabular} in a completely mixed batch reactor system}

TNDMA-N-nitrosodimethylamine

$\ddagger$ Super-Q, $\odot$ Millipore Corp., Bedford, Mass.

${ }^{*}{ }^{*} \mathrm{H}_{2} \mathrm{O}_{2}$-hydrogen peroxide

t†NA-not applicable

TABLE 4 Effects of $\mathrm{NO}_{3}-$ on NDMA reduction in Southern California groundwater

\begin{tabular}{|c|c|c|c|c|c|c|}
\hline \multirow[b]{2}{*}{$\begin{array}{l}\text { Sampling } \\
\text { Location }\end{array}$} & \multirow[b]{2}{*}{$\begin{array}{c}\text { UV } \\
\text { Dose } \\
k W \cdot h / 1,000 \mathrm{gal}\end{array}$} & \multicolumn{2}{|c|}{ Pulsed-UV† Alone } & \multicolumn{3}{|c|}{ Pulsed-UV + $1.0 \mathrm{mg} / \mathrm{L} \mathrm{H}_{2} \mathrm{O}_{2} \ddagger$} \\
\hline & & $\begin{array}{c}\text { NDMA } \\
n g / L\end{array}$ & $\begin{array}{l}\mathrm{NO}_{3}^{-} \\
m g / L\end{array}$ & $\begin{array}{c}\text { NDMA } \\
\mu g / L\end{array}$ & $\begin{array}{l}\mathrm{NO}_{3}^{-} \\
\mathrm{mg} / \mathrm{L}\end{array}$ & $\begin{array}{c}\mathrm{H}_{2} \mathrm{O}_{2} \\
\text { Residual } \\
\mu \mathrm{g} / \mathrm{L}\end{array}$ \\
\hline Influent & NA§ & 2,300 & 41.6 & 2,400 & 39.9 & NA§ \\
\hline Effluent & 11.2 & 140 & 37 & 110 & 37.2 & NA \\
\hline \multicolumn{2}{|c|}{ Percent removal } & $93.9 \%$ & NA & $95.4 \%$ & NA & NA \\
\hline
\end{tabular}
at $25 \mathrm{~Hz}$ in a continuously stirred tank reactor system*

* $\mathrm{NO}_{3}-$-nitrate, $\mathrm{NDMA}-\mathrm{N}$-nitrosodimethylamine

$\neq \mathrm{H}_{2} \mathrm{O}_{2}$ - hydrogen peroxide

$\S N A-$ not applicable

Effects of initial NDMA* concentration on NDMA reduction in Southern

\begin{tabular}{|c|c|c|c|c|c|c|}
\hline \multirow[b]{2}{*}{$\begin{array}{l}\text { Sampling } \\
\text { Location }\end{array}$} & \multirow[b]{2}{*}{$\begin{array}{c}\text { UV } \\
\text { Dose } \\
k W \cdot h / 1,000 \mathrm{gal}\end{array}$} & \multicolumn{3}{|c|}{ Pulsed-UV† Alone } & \multicolumn{2}{|c|}{$\begin{array}{l}\text { Pulsed-UV + } \\
1.0 \mathrm{mg} / \mathrm{L} \mathrm{H}_{2} \mathrm{O}_{2} \neq\end{array}$} \\
\hline & & $\begin{array}{c}\text { Test } 1 \\
\text { NDMA } \\
n g / L\end{array}$ & $\begin{array}{c}\text { Test } 2 \\
\text { NDMA } \\
n g / L\end{array}$ & $\begin{array}{c}\text { Test } 3 \\
\text { NDMA } \\
n g / L\end{array}$ & $\begin{array}{l}\mathrm{NDMA}^{-} \\
n g / \mathrm{L}^{-}\end{array}$ & $\begin{array}{c}\mathrm{H}_{2} \mathrm{O}_{2} \\
\text { Residual } \\
\mu \mathrm{g} / \mathrm{L}\end{array}$ \\
\hline Influent & NA§ & 2,800 & 100 & 100 & 92 & NA \\
\hline Effluent & 11.2 & 30 & 19 & 1.6 & 1.5 & NA \\
\hline \multicolumn{2}{|l|}{ Percent removal } & $98.9 \%$ & $98.1 \%$ & $98.4 \%$ & $98.3 \%$ & NA \\
\hline
\end{tabular}
California groundwater at $25 \mathrm{~Hz}$ in a continuously stirred tank reactor system 


\begin{tabular}{|c|c|c|c|c|c|c|c|c|}
\hline \multicolumn{4}{|c|}{ NDMA in Southern California Groundwater } & \multicolumn{5}{|c|}{ NDMA in Deionized Water $†$} \\
\hline $\begin{array}{c}\text { UV } \\
\text { Dose } \\
k W \cdot h / 1,000 \mathrm{gal}\end{array}$ & $\begin{array}{l}\text { Pulsed- } \\
\text { UV Alone } \\
n g / L\end{array}$ & $\begin{array}{l}\text { Pulsed-UV + } \\
1 \mathrm{mg} / \mathrm{L} \mathrm{H}_{2} \mathrm{O}_{2} \\
n g / \mathrm{L}\end{array}$ & $\begin{array}{c}\mathrm{H}_{2} \mathrm{O}_{2} \\
\text { Residual } \\
\mu \mathrm{g} / \mathrm{L}\end{array}$ & $\begin{array}{c}\text { UV } \\
\text { Dose } \\
k W \cdot h / 1,000 \mathrm{gal}\end{array}$ & $\begin{array}{l}\text { Pulsed- } \\
\text { UV Alone } \\
n g / L\end{array}$ & $\begin{array}{c}\text { UV } \\
\text { Dose } \\
k W \cdot h / 1,000 \mathrm{gal}\end{array}$ & $\begin{array}{c}\text { Pulsed-UV + } \\
1 \mathrm{mg} / \mathrm{L} \mathrm{H} \mathrm{O}_{2} \\
n g / \mathrm{L}\end{array}$ & $\begin{array}{c}\mathrm{H}_{2} \mathrm{O}_{2} \\
\text { Residual } \\
\mu \mathrm{g} / \mathrm{L}\end{array}$ \\
\hline 11.2 & 1.6 & 1.5 & NA§ & 5.7 & 58 & 8.6 & 19 & 800 \\
\hline $\begin{array}{l}1 \mathrm{mg} / \mathrm{L} \mathrm{Cl}_{2}^{* * *} \\
\text { for five days }\end{array}$ & 3.9 & 1.5 & NA§ & $\begin{array}{c}1 \mathrm{mg} / \mathrm{L} \mathrm{Cl}_{2} \\
\text { for five days }\end{array}$ & 99 & $\begin{array}{c}1 \mathrm{mg} / \mathrm{L} \mathrm{Cl}_{2} \\
\text { for five days }\end{array}$ & 35 & NA \\
\hline
\end{tabular}

${ }^{*} \mathrm{H}_{2} \mathrm{O}_{2}$-hydrogen peroxide, NDMA- $\mathrm{N}$-nitrosodimethylamine

tSuper-Q, $\odot$ Millipore Corp., Bedford, Mass.

+UV-ultraviolet

§NA—not applicable

${ }^{*}{ }^{*} \mathrm{Cl}_{2}$-chlorine

7.15 , and $2.2 \mathrm{~min}^{-1}$ for pulsed-light inputs of 25,10 , and $2 \mathrm{~Hz}$, respectively. A comparison of the kinctic rates of NDMA decay at pulsed-light inputs of 25, 10, and 2 $\mathrm{Hz}$ suggests that strong pulsed-UV intensity is produced at the high pulsed-light input of $25 \mathrm{~Hz}$, resulting in more effective reduction of NDMA. However, optimization of the energy input (frequency) may be needed in the design of a pulsed-UV system.

Effects of source water. Different source water supplies, such as Southern California groundwater and CRW spiked with NDMA, were irradiated at the pulsedlight input of $10 \mathrm{~Hz}$ (Figure 5). Over the duration of the experiments $(<5 \mathrm{~min})$, the $\mathrm{pH}$ of the water did not change significantly. NDMA removals of $98 \%$ in Southern California groundwater and $82 \%$ in CRW were achieved with an applied pulsed-UV dose of 5.2 $\mathrm{kW} \cdot \mathrm{h} / 1,000 \mathrm{gal}$. The kinetic rates of NDMA decay were $4.1 \mathrm{~min}^{-1}$ in Southern California groundwater and 1.4 $\mathrm{min}^{-1}$ in CRW. The results might suggest a strong competition for the pulsed-light absorption between NDMA and background organic compounds (e.g., TOC or a UV-absorbing organic) in Southern California groundwater and CRW. It appeared that pulsed-UV alone was more effective in destroying NDMA in the Southern California groundwater than in CRW, because CRW contained higher levels of both background organic compounds (which may compete for pulsed UV) and turbidity (which reduces the applied UV as a result of the lower transmittance) than did the Southern California groundwater.

Effects of $\mathbf{U V} / \mathrm{H}_{2} \mathbf{O}_{2}$. The rate of NDMA dissociation by UV is much faster than the rate of NDMA oxidation by hydroxyl radicals; thus, the addition of $\mathrm{H}_{2} \mathrm{O}_{2}$ does not necessarily increase the NDMA removal efficiency. Furthermore, $\mathrm{H}_{2} \mathrm{O}_{2}$ only weakly absorbs pulsed-UV light at a peak wavelength of $200 \mathrm{~nm}$ compared with NDMA. NIDMA-spiked DI water was irradiated in the presence of $\mathrm{H}_{2} \mathrm{O}_{2}$. The effects of $\mathrm{H}_{2} \mathrm{O}_{2}$ on NDMA removal with 0.1 and $1.0 \mathrm{mg} / \mathrm{L} \mathrm{H}_{2} \mathrm{O}_{2}$ (at molar $\mathrm{H}_{2} \mathrm{O}_{2}$-to-NDMA ratios of 68 and 784) were investigated at a pulsed-UV input of 10
$\mathrm{Hz}$ (Figures 5 and 6). With the addition of $\mathrm{H}_{2} \mathrm{O}_{2}$, the kinetic rates of NDMA decay were 7.16 and $7.24 \mathrm{~min}^{-1}$ for 0.1 and $1.0 \mathrm{mg} / \mathrm{L} \mathrm{H}_{2} \mathrm{O}_{2}$, respectively. Compared with the use of pulsed-UV alone at $10 \mathrm{~Hz}$, the addition of $\mathrm{H}_{2} \mathrm{O}_{2}$ did not significantly increase the kinetic rate of NDMA decay. These results showed that pulsed-UV alone and pulsed-UV with a low concentration of $\mathrm{H}_{2} \mathrm{O}_{2}$ were equally effective in reducing NDMA.

Because NDMA removal is primarily accomplished by direct photolysis, rather than by hydroxyl radicals, the presence of a small amount of $\mathrm{H}_{2} \mathrm{O}_{2}$ had no major effect on the efficiency of NDMA removal. Similar results were observed in NDMA-spiked Southern California groundwater and CRW (Figure 5). However, the presence of a high concentration of $\mathrm{H}_{2} \mathrm{O}_{2}(79 \mathrm{mg} / \mathrm{L})$ significantly hindered NDMA reduction because of the strong competition for UV light by the high concentration of $\mathrm{H}_{2} \mathrm{O}_{2}$ (Figure 7). The kinetic rate decreased from 7.15 min-1 in the absence of the $\mathrm{H}_{2} \mathrm{O}_{2}$ spike to $2.44 \mathrm{~min}^{-1}$ with the addition of $79 \mathrm{mg} / \mathrm{L} \mathrm{H}_{2} \mathrm{O}_{2}$. The production of hydroxyl radicals from $\mathrm{H}_{2} \mathrm{O}_{2}$ did not improve NDMA reduction, because the oxidation of NDMA by hydroxyl radicals is much slower compared with direct photolysis of NDMA. In fact, the addition of a high concentration of $\mathrm{H}_{2} \mathrm{O}_{2}$ resulted in a decreased NDMA decay rate because of the strong competition for UV light in the presence of a high concentration of $\mathrm{H}_{2} \mathrm{O}_{2}$. Thus, $\mathrm{H}_{2} \mathrm{O}_{2}$ dosage should be optimized if it must be added to inhibit reformation of NDMA upon chlorination of UV-treated effluent.

Effects of $\mathrm{NO}_{3}$. The UV absorption spectrum of aqueous $\mathrm{NO}_{3}{ }^{-}$solution features two bands in the ranges of 230-240 $\mathrm{nm}$ and $300-310 \mathrm{~nm}$, which are close to the absorption bands of the aqueous NDMA solution (Calgon Carbon, 1996). For the direct photolysis process, a strong competition for UV light absorption between $\mathrm{NO}_{3}^{-}$ ions and NDMA can reduce the effectiveness of NDMA removal. In addition to direct photolysis of $\mathrm{NO}_{3}{ }^{-}$ions, the irradiation of $\mathrm{NO}_{3}{ }^{-}$in its long-wavelength absorption at the maximum of $302 \mathrm{~nm}$ results in two primary photo- 
chemical pathways (Warneck \& Würzinger, 1988; Zepp et al, 1987), as shown in Eq 4.

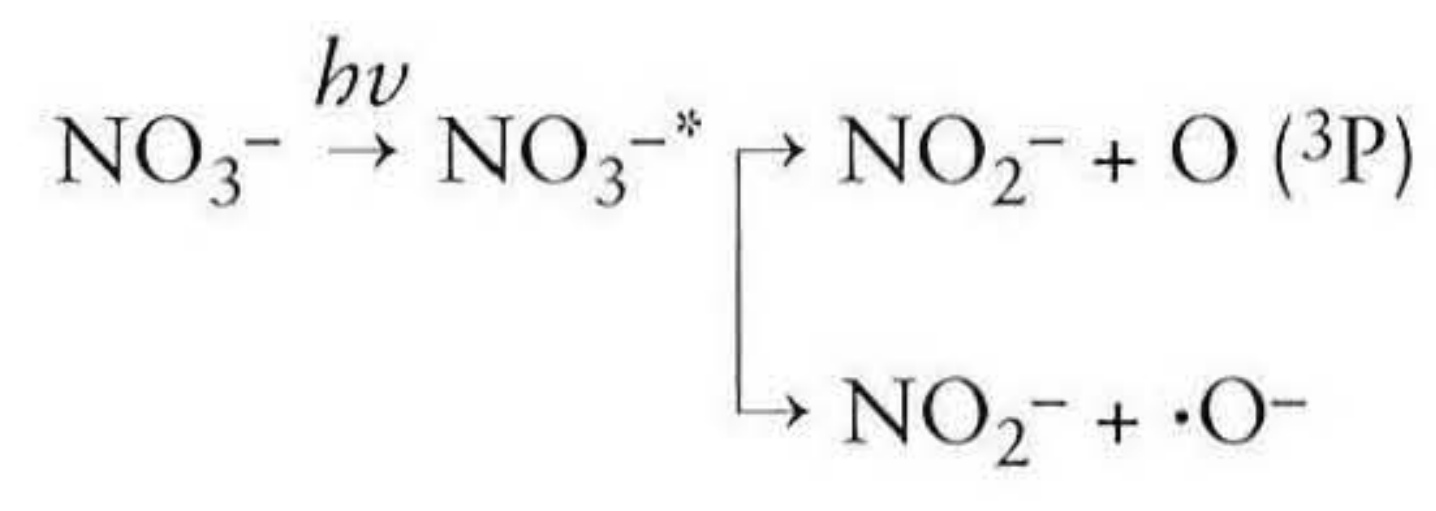

The $\cdot \mathrm{O}^{-}$radical ion generated by the reaction pathway shown in $\mathrm{Eq} 4$ subsequently combines with a proton to form a hydroxyl radical. It is suggested that photochemically induced hydroxyl radicals from $\mathrm{NO}_{3}{ }^{-}$may oxidize organic chemicals such as NDMA. However, in some cases, the net effect may be small or even negative, because $\mathrm{NO}_{3}{ }^{-}$competes for UV light, which is the dominant source of the NDMA removal mechanism.

NDMA-spiked DI water was irradiated in the presence of $\mathrm{NO}_{3}{ }^{-}$at a pulsed-light input of $10 \mathrm{~Hz}$ in the CMBR (Table 3). The kinetic rate of NDMA decay decreased from $7.15 \mathrm{~min}^{-1}$ in the absence of $\mathrm{NO}_{3}{ }^{-}$to $2.76 \mathrm{~min}^{-1}$ in the presence of $38 \mathrm{mg} / \mathrm{L} \mathrm{NO}_{3}^{-}$(Figure 6). It is apparent that $\mathrm{NO}_{3}{ }^{-}$competed with NDMA for UV light, consequently limiting the effectiveness of direct photolysis in breaking down NDMA. As discussed earlier, the results did not show any nitrate-induced, photooxidation-enhanced NDMA reduction, because hydroxyl radical-mediated NDMA oxidation is a slower process than direct photolysis of NDMA by UV.
With the addition of $1.0 \mathrm{mg} / \mathrm{L} \mathrm{H}_{2} \mathrm{O}_{2}$, the kinetic rate of NDMA decay changed only insignificantly (from 2.76 to $2.82 \mathrm{~min}^{-1}$ ) in the presence of $\mathrm{NO}_{3}^{-}$, as previously shown. Similarly, in a CSTR system, no significant difference in NDMA removal was shown between the use of pulsed-UV alone $(93.9 \%)$ and pulsed-UV with $1.0 \mathrm{mg} / \mathrm{L}$ $\mathrm{H}_{2} \mathrm{O}_{2}(95.4 \%)$ in the presence of approximately $40 \mathrm{mg} / \mathrm{L}$ $\mathrm{NO}_{3}{ }^{-}$in Southern California groundwater at the pulsedUV input of $25 \mathrm{~Hz}$. Under all tested conditions, $\mathrm{NO}_{3}{ }^{-}$ was reduced only up to $11 \%$, in contrast with the NDMA removal of $>90 \%$ (Table 4 ).

Effects of initial NDMA concentration in a CSTR system. Southern California groundwater, spiked at two concentrations $(2,800$ and $100 \mathrm{ng} / \mathrm{L}$ ) of NDMA, was irradiated at the applied pulsed frequency of $25 \mathrm{~Hz}$ in a CSTR system (Table 5). Pulsed UV alone achieved NDMA removals of $98 \%$ at these conditions when applied at a UV dose of $11.2 \mathrm{~kW} \cdot \mathrm{h} / 1,000$ gal. The retention time of $1.75 \mathrm{~min}$ provided a sufficient UV dosage for the test using a low NDMA concentration $(<2,800 \mathrm{ng} / \mathrm{L})$ to yield $<2 \mathrm{ng} / \mathrm{L}$ effluent NDMA concentration. However, a longer retention time at an applied UV dose of 11.2 $\mathrm{kW} \cdot \mathrm{h} / 1,000 \mathrm{gal}$ would be needed for the testing using a higher NDMA spike (>2,800 ng/L), when the effluent concentration was $30 \mathrm{ng} / \mathrm{L}$-exceeding the proposed action level set by the CDHS.

Reformation/regeneration of NDMA. The reformation/ regeneration of NDMA is of concern because the degradation products from the photolytic destruction of NDMA

TABLE 7

Effects of NDMA* destruction on disinfection by-product formation in a Southern California groundwater

\begin{tabular}{|c|c|c|c|c|c|c|}
\hline \multirow[b]{2}{*}{ Compound } & \multicolumn{3}{|c|}{ No NDMA Spiking } & \multicolumn{3}{|c|}{ NDMA Spiking With a Concentration of 3,000 ng/L } \\
\hline & $\begin{array}{l}\text { No Pulsed- } \\
\text { UV† Treatment }\end{array}$ & $\begin{array}{l}\text { Pulsed- } \\
\text { UV Alone }\end{array}$ & $\begin{array}{l}\text { Pulsed-UV + } \\
1 \mathrm{mg} / \mathrm{L} \mathrm{H}_{2} \mathrm{O}_{2} \ddagger\end{array}$ & $\begin{array}{l}\text { No Pulsed-UV } \\
\text { Treatment }\end{array}$ & $\begin{array}{l}\text { Pulsed- } \\
\text { UV Alone }\end{array}$ & $\begin{array}{l}\text { Pulsed-UV + } \\
1 \mathrm{mg} / \mathrm{L} \mathrm{H}_{2} \mathrm{O}_{2}\end{array}$ \\
\hline \multicolumn{7}{|l|}{ Trihalomethanes $-\mu g / L$} \\
\hline Chloroform & 0.27 & 0.23 & 0.3 & 0.17 & $<0.1$ & 1.28 \\
\hline Dichlorobromomethane & 0.42 & 0.52 & 0.44 & 0.26 & 0.11 & 1.31 \\
\hline Dibromochloromethane & 0.45 & 0.55 & 0.49 & 0.25 & 0.21 & 0.96 \\
\hline Bromoform & $<0.1$ & 0.13 & 0.12 & $<0.1$ & 0.36 & 0.19 \\
\hline Total & 1.14 & 1.43 & 1.35 & 0.68 & 0.68 & 3.74 \\
\hline \multicolumn{7}{|l|}{ Haloacetic nitriles $-\mu g / L$} \\
\hline Dibromoacetonitrile & 0.26 & NA§ & NA & NA & NA & NA \\
\hline Bromochloroacetonitrile & 0.17 & 0.22 & 0.19 & 0.13 & 0.13 & NA \\
\hline Dichloroacetonitrile & $<0.1$ & NA & NA & NA & $<0.1$ & 0.14 \\
\hline Trichloroacetonitrile & NA & NA & NA & NA & NA & NA \\
\hline \multicolumn{7}{|l|}{ Haloketones- $\mu g / L$} \\
\hline 1,1-Dichloropropanone & $<0.1$ & $<0.1$ & $<0.1$ & $<0.1$ & $<0.1$ & $<0.1$ \\
\hline 1,1,1-Trichloropropanone & $<0.1$ & $<0.1$ & $<0.1$ & $<0.1$ & $<0.1$ & $<0.1$ \\
\hline Chloropicrin- $\mu g / L$ & $<0.1$ & $<0.1$ & $<0.1$ & $<0.1$ & $<0.1$ & 0.15 \\
\hline
\end{tabular}

*NDMA $-N$-nitrosodimethylamine

tUV-ultraviolet

$\neq \mathrm{H}_{2} \mathrm{O}_{2}$ - hydrogen peroxide

$\S N A-$ not applicable 
could recombine to form NDMA after chlorinating the UV-treated effluent. Samples taken for the NDMA reformation study were dosed with $1 \mathrm{mg} / \mathrm{L} \mathrm{Cl}_{2}$ for five days at 4 to $8^{\circ} \mathrm{C}$. For the test with Southern California groundwater, NDMA concentrations increased from 1.6 (after the UV dose of $11.2 \mathrm{~kW} \cdot \mathrm{h} / 1,000 \mathrm{gal}$ ) to $3.9 \mathrm{ng} / \mathrm{L}$, whereas NDMA concentrations did not change for the sample in which NDMA was treated with UV combined with 1.0 $\mathrm{mg} / \mathrm{L} \mathrm{H}_{2} \mathrm{O}_{2}$ (Table 6). In addition, reformation/regeneration of NDMA was also observed in DI water spiked with 3,000 ng/L NDMA and $40 \mathrm{mg} / \mathrm{L} \mathrm{NO}_{3}{ }^{-}$. After chlorination, NDMA concentrations increased from $58 \mathrm{ng} / \mathrm{L}$ (for pulsed-UV alone after a UV dose of $5.7 \mathrm{~kW} \cdot \mathrm{h} / 1,000$ gal) to $99 \mathrm{ng} / \mathrm{L}$ and from $19 \mathrm{ng} / \mathrm{L}$ (after a UV dose of 8.6 $\mathrm{kW} \cdot \mathrm{h} / 1,000$ gal combined with $1.0 \mathrm{mg} / \mathrm{L} \mathrm{H}_{2} \mathrm{O}_{2}$ ) to 35 $\mathrm{ng} / \mathrm{L}$. It is apparent that the pulsed-UV/ $\mathrm{H}_{2} \mathrm{O}_{2}$ process was more effective than pulsed-UV alone in inhibiting NDMA reformation. However, the development of an exact mechanism for such behavior will need further investigation.

DBPs. The SDS test was used to estimate the amounts of DBPs that would form in the distribution systems (Table 7). The DBPs analyzed included THMs (chloroform, dichlorobromomethane, dibromochloromethane, bromoform); HANs (dibromoacetonitrile, bromochloroacetonitrile, dichloroacetonitrile, trichloroacetonitrile); HKs (1,1-dichloropropanone and 1,1,1-trichloropropanone); and chloropicrin. For the control samples without NDMA addition, no significant change in THMs, HANs, HKs, or chloropicrin was observed among SDS test samples taken from different treatment processes (e.g., without pulsed-UV, with pulsed-UV, and with pulsed-UV combined with $\left.1 \mathrm{mg} / \mathrm{L} \mathrm{H}_{2} \mathrm{O}_{2}\right)$. With an NDMA spike of 3,000 $\mathrm{ng} / \mathrm{L}$, TTHMs were formed in concentrations of 0.68 and $3.74 \mu \mathrm{g} / \mathrm{L}$ after treatment by pulsed-UV alone and by pulsed UV combined with $1 \mathrm{mg} / \mathrm{L}_{2} \mathrm{H}_{2} \mathrm{O}_{2}$, respectively. Higher concentrations of chlorinated THMs were formed after the advanced oxidation process (pulsed- $\mathrm{UV} / \mathrm{H}_{2} \mathrm{O}_{2}$ ), whereas higher concentrations of brominated THMs were formed after photolysis (pulsed-UV alone). In the presence of NDMA, the DBPs (e.g., HANs, HKs, and chloropicrin) did not change significantly among SDS test samples taken from different experiments.

Residual $\mathbf{H}_{2} \mathbf{O}_{2}$. As mentioned previously, $\mathrm{H}_{2} \mathrm{O}_{2}$ is a weaker absorber of pulsed-UV light at a peak wavelength of $200 \mathrm{~nm}$ than is NDMA. In general, addition of $\mathrm{H}_{2} \mathrm{O}_{2}$ in the pulsed-UV/ $\mathrm{H}_{2} \mathrm{O}_{2}$ process resulted in only a small reduction of $\mathrm{H}_{2} \mathrm{O}_{2}$. According to the analyses done for $\mathrm{H}_{2} \mathrm{O}_{2}$ residuals, only up to $20 \%$ of $\mathrm{H}_{2} \mathrm{O}_{2}$ was reduced in the tests. The addition of $\mathrm{H}_{2} \mathrm{O}_{2}$ did not necessarily enhance destruction of NDMA by the hydroxyl radicals produced from $\mathrm{H}_{2} \mathrm{O}_{2}$, but the presence of $\mathrm{H}_{2} \mathrm{O}_{2}$ seemed to inhibit reformation of NDMA and production of DBPs.

\section{SUMMARY AND CONCLUSIONS}

On the basis of the tests performed, the following conclusions can be drawn regarding the effectiveness of
pulsed-UV irradiation and pulsed-UV/ $\mathrm{H}_{2} \mathrm{O}_{2}$ processes for the destruction of NDMA:

- The results generated from bench-scale testing in both the CMBR and CSTR systems indicated that pulsedUV alone was effective in removing NDMA. For example, pulsed-UV alone achieved NDMA removals of $98 \%$ at initial concentrations of 2,800 and $100 \mathrm{ng} / \mathrm{L}$ NDMA in Southern California groundwater with an applied UV dose of $11.2 \mathrm{~kW} \cdot \mathrm{h} / 1,000 \mathrm{gal}$ in both the CMBR and CSTR modes.

- Although the addition of low concentrations of $\mathrm{H}_{2} \mathrm{O}_{2}$ does not significantly enhance removal of NDMA or increase the kinetic rate of NDMA decay, the pulsed$\mathrm{UV} / \mathrm{H}_{2} \mathrm{O}_{2}$ process was more effective in oxidizing NDMA by-products than was pulsed-UV alone and resulted in less reformation of NDMA after chlorination. The addition of a high concentration of $\mathrm{H}_{2} \mathrm{O}_{2}$ slowed down the reduction of NDMA.

- Applied pulsed-UV dosage was the most significant parameter affecting the percentage of NDMA reduction. In a CMBR system, NDMA reduction increased with increasing UV dosage at a constant pulse input (frequency). For example, NDMA removals of 69 and $88 \%$ in DI water were achieved with applied UV doses of 1.3 and $2.6 \mathrm{~kW} \cdot \mathrm{h} / 1,000$ gal, respectively, at a pulse input of $2 \mathrm{~Hz}$.

- The kinetic rates of NDMA decay at pulse rates of 25,10 , and $2 \mathrm{~Hz}$ suggest that a strong UV intensity produced at the pulse rate of $25 \mathrm{~Hz}$ resulted in more effective reduction of NDMA.

- A strong competition between NDMA and background organics (e.g., TOC and $\mathrm{UV}_{254}$-absorbing organic compounds) for pulsed-light absorption affected NDMA removal. Pulsed-UV alone was more effective in destroying NDMA in Southern California groundwater than in CRW, possibly because higher levels of background organic compounds are present in CRW than in the Southern California groundwater used for this study.

- $\mathrm{NO}_{3}{ }^{-}$competed with NDMA for UV light and consequently limited the effectiveness of direct photolysis of NDMA. The test results did not indicate that the nitrateinduced photooxidation enhanced NDMA reduction.

- Pulsed-UV/ $/ \mathrm{H}_{2} \mathrm{O}_{2}$ produced higher TTHMs than pulsed-UV alone. With an NDMA spike of 3,000 ng/L, TTHMs were formed in concentrations of 0.68 and 3.74 $\mu \mathrm{g} / \mathrm{L}$, respectively, after treatment by pulsed-UV alone and by pulsed-UV combined with $1 \mathrm{mg} / \mathrm{L} . \mathrm{H}_{2} \mathrm{O}_{2}$.

\section{ACKNOWLEDGMENT}

The authors thank Lambert Arzadon, Brian Maul, Michael Tapper, and Michael Landesman of Harvey Mudd College, Claremont, Calif., and Remleh Scherzinger of the Sonoma County (Calif.) Water District for their assistance in operating the batch-scale reactor. The authors also acknowledge the contributions of Robert Alvarez, Warren Schimpff, and Sikha Kundu of the Metropolitan 
Water District of Southern California's Water Quality Laboratory, who provided invaluable assistance in analyzing the water samples. Thanks are also extended to Peggy Kimball, who reviewed the manuscript. This work was partially funded by a grant from Edison Technology Solutions, the Electric Power Research Institute, and the California Energy Commission.

\section{ABOUT THE AUTHORS:}

Sun Liang ${ }^{7}$ is program manager for advanced water treatment issues with the Metropolitan Water District of Southern California (MWDSC), 700 Moreno Ave., La Verne, CA 917.50; e-mail sliang@mwdH2O.com.us.

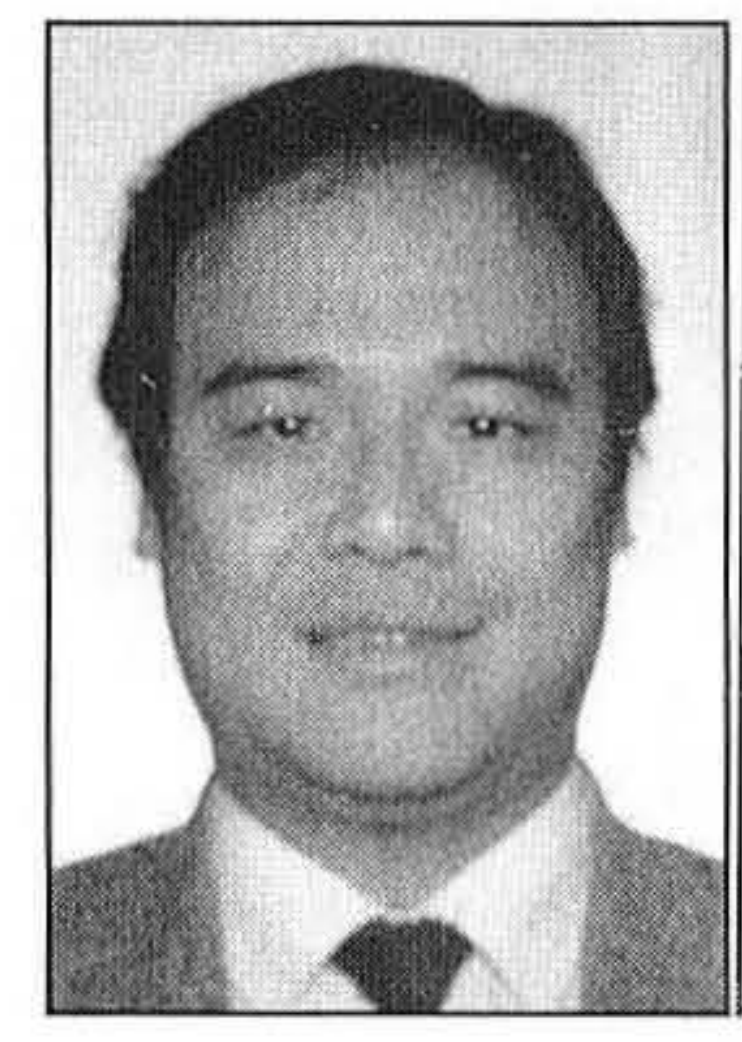

He received his $B S$ degree in agricultural engineering from the National Taiwan University in Taipei and his $M S$ and PhD degrees in civil engineering from the University of California, Berkeley, and the University of Michigan, Ann Arbor, respectively. He has been conducting research in the field of water and wastewater treatment technologies for 26 years and has been working in advanced oxidation processes, including ultraviolet (UV) and UV/bydrogen peroxide, for the past five years. Joon $\mathrm{H}$. Min is a project engineer for Carollo Engineers in Santa Ana, Calif. Marshall K. Davis is manager of the Chemistry Unit and James F. Green is manager of the Water Treatment Section, both with MWDSC. Donald $S$. Remer is a professor of engineering with Harvey Mudd College in Claremont, Calif.

\section{FOOTNOTES}

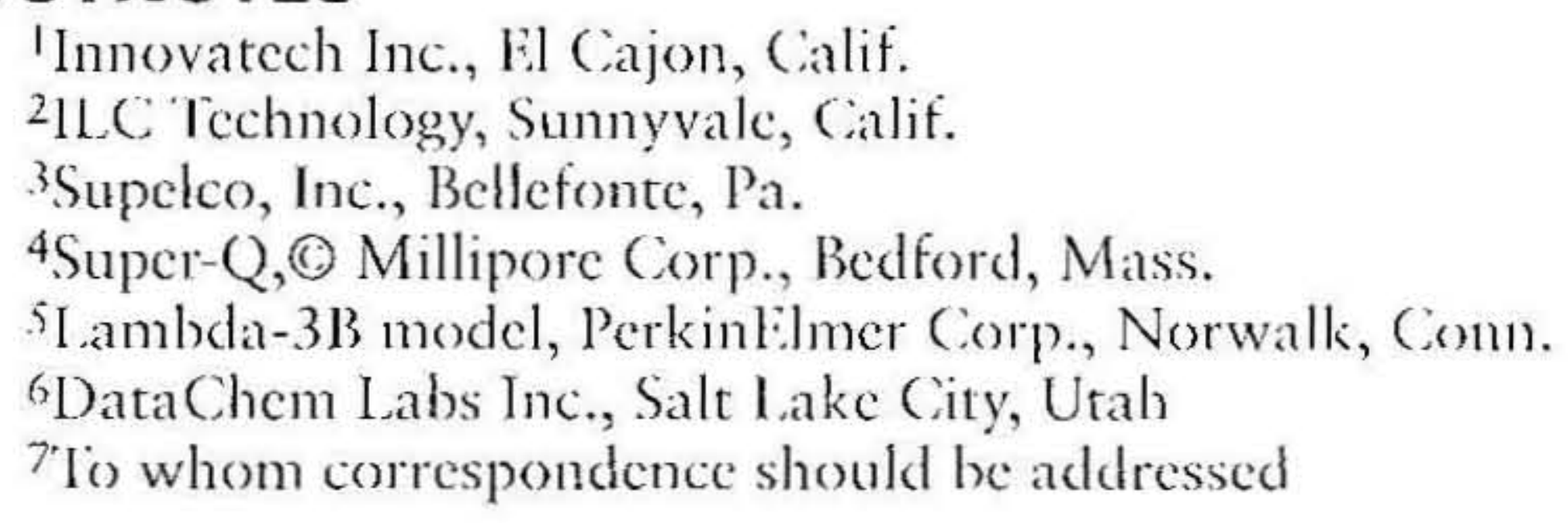

If you have a comment about this article, please contact us at journal@awwa.org.

\section{REFERENCES}

Bircher, K.G. et al, 1999. Treatment of NDMA in Drinking Water by a Rayox UV Tower. Proc. 1999 Perchlorate Conf., East Valley Municipal Water District, Ontario, Calif.

Bolton, J.R. et al, 2001. Ultraviolet Treatment and Potential Formation of $\mathrm{N}$-nitrosodimethylamine in a Water Reclamation Treatment Plant. Proc. 1st Ann. Congress, Intl. Ultraviolet Assn., Washington.

Brennan, P. \& Robbins, G., 2000. Carcinogen Found in O.C. Wells: Health Agency Says Chemical's Presence Is Minimal and Water Supply Is Safe. Orange County Register(May 31), www.ocregister.com/archives.

Buxton, G.V. et al, 1988. Critical Review of Rate Constants for Hydrated Electrons, Hydrogen Atoms, and Hydroxyl Radicals $\left(\mathrm{OH} / \mathrm{O}^{-}\right)$in Aqueous Solution. Jour. Phys. \& Chem. Ref. Data, 17:2:513.

Calgon Carbon Oxidation Technologies, 1996. Calgon AOT Handbook. Calgon, Markham, Ont.

CDHS (California Department of Health Services), 2003. California Drinking Water NDMA-related Activities. Div. Drinking Water and Envir. Mgmt., Sacramento, Calif. www.dhs.ca.gov/ps/ddwem/chemicals/NDMA/history.htm.

CDHS, 2000. California Drinking Water NDMArelated Activities. Div. Drinking Water and Envir. Mgmt., Sacramento, Calif. www.dhs.cahwnet.gov/ps/ddwem/chemi cals/NDMA/NDMAindex.htm.

Challis, B.C. et al, 1978. Rapid Formation of $\mathrm{N}$-nitrosamines From Nitrogen 0xides Under Neutral and Alkaline Conditions. Proc. Working Conf. on Envir. Aspects of N-nitroso Compounds. New England Center for Continuing Education, Univ. of New Hampshire, Durham.

Choi, J. et al, 2001. Studies on the Formation of $\mathrm{N}$-nitrosodimethylamine in Drinking Water: A New Chloramination Disinfection By-product. Proc. 2001 AWWA Ann. Conf., Washington.

Davis, M.K. et al, 2000. N-nitrosodimethylamine in Surface Water. Proc. 2000 AWWA WOTC, Salt Lake City.

Jobb, D.B. et al, 1994. Removal of $N$-nitrosodimethylamine From the Ohsweken (Six Nations) Water Supply. Final Report, Ontario Ministry of Environment and Energy, Toronto.

Jobb, D.B. et al, 1992. A Study of the Occurrence and Inhibition of Formation of $\mathrm{N}$ nitrosodimethylamine in the Ohsweken Water Supply. Proc. 5th Natl. Conf. on Drinking Water, Winnipeg, Man.

Koch, B. et al, 1988. Analysis of Halogenated Disinfection By-products by Capillary Chromatography. Proc. 1988 AWWA WQTC, St. Louis.

Kok, G.L.; Thompson, K.; \& Lazrus, A.L., 1986. Derivatization Technique for the Determination of Peroxides in Precipitation. Anal. Chem., 58:6:1192.
MOE (Ministry of the Environment), 1991. Scientific Criteria Document for Multimedia Standard Development No. 01-90: Nnitrosodimethylamine. MOE Hazardous Contaminants Coordination Branch, Etobicoke, Ont.

Sharpless, C.M. et al, 2001. A Comparison of Monochromatic Versus Polychromatic $\mathrm{Hg}$ Lamps for Direct Photolysis and $\mathrm{H}_{2} \mathrm{O}_{2}$-assisted UV Photodegradation on $\mathrm{N}$-nitrosodimethylamine in Drinking Water. Proc. 1st Ann. Congress, Intl. Ultraviolet Assn., Washington.

Smith, B., 1986. Overview of Flashlamps and Arc Lamps. Proc. 1986 Flashlamp Pumped Laser Technol. Conf., Intl. Soc. for Optical Engrg., Los Angeles.

Standard Methods for the Examination of Water and Wastewater, 1995 (19th ed.). APHA, AWWA, and WEF, Washington.

Taguchi, V.Y. et al, 1994. Determination of $\mathrm{N}$ nitrosodimethylamine by Isotope Dilution, High-resolution Mass Spectrometry. Canadian Jour. Applied Spectros., 39:3:87.

Warneck, P. \& Würzinger, C., 1988. Product Quantum Yields for 305-nm Photodecomposition of $\mathrm{NO}_{3}{ }^{-}$in Aqueous Solution. Jour. Phys. Chem., 92:22:6278.

Zepp, R.G.; Hoigné, J.; \& Bader, H., 1987. Nitrate-induced Photooxidation of Trace Organic Chemicals in Water. Envir. Sci. \& Technol., 21:5:443. 